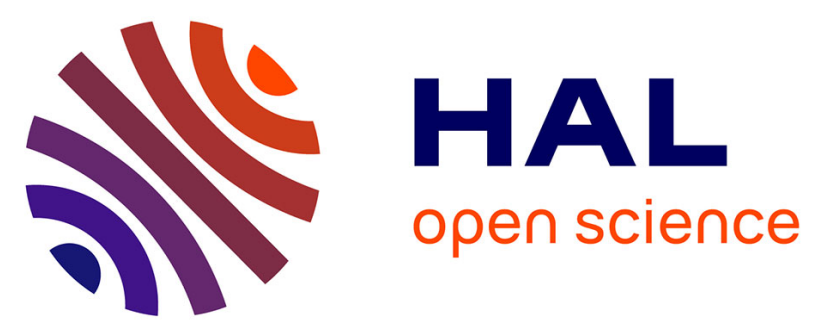

\title{
Inter-specific competition in mixed forests of Douglas-fir (Pseudotsuga menziesii) and common beech (Fagus sylvatica) under climate change - a model-based analysis
}

Christopher Reyer, Petra Lasch, Godefridus M.J. Mohren, Frank J. Sterck

\section{- To cite this version:}

Christopher Reyer, Petra Lasch, Godefridus M.J. Mohren, Frank J. Sterck. Inter-specific competition in mixed forests of Douglas-fir (Pseudotsuga menziesii) and common beech (Fagus sylvatica) under climate change - a model-based analysis. Annals of Forest Science, 2010, 67 (8), 10.1051/forest/2010041 . hal-00883648

\section{HAL Id: hal-00883648 https://hal.science/hal-00883648}

Submitted on 1 Jan 2010

HAL is a multi-disciplinary open access archive for the deposit and dissemination of scientific research documents, whether they are published or not. The documents may come from teaching and research institutions in France or abroad, or from public or private research centers.
L'archive ouverte pluridisciplinaire HAL, est destinée au dépôt et à la diffusion de documents scientifiques de niveau recherche, publiés ou non, émanant des établissements d'enseignement et de recherche français ou étrangers, des laboratoires publics ou privés. 


\title{
Inter-specific competition in mixed forests of Douglas-fir (Pseudotsuga menziesii) and common beech (Fagus sylvatica) under climate change - a model-based analysis
}

\author{
Christopher REYER ${ }^{1,2 *}$, Petra LASCH${ }^{1}$, Godefridus M.J. MOHREN ${ }^{2}$, Frank J. STERCK ${ }^{2}$ \\ ${ }^{1}$ Potsdam Institute for Climate Impact Research, Telegrafenberg A62/1.09, 14412 Potsdam, Germany \\ ${ }^{2}$ Forest Ecology and Management Group, Wageningen University and Research
}

(Received 13 January 2010; accepted 17 April 2010)

Keywords:

climate change /

competition /

forest modelling /

mixed forests

\begin{abstract}
- Mixed forests feature competitive interactions of the contributing species which influence their response to environmental change.

- We analyzed climate change effects on the inter-specific competition in a managed Douglasfir/beech mixed forest.

- Therefore, we initialised the process-based forest model 4C with published fine root biomass distributions of Douglas-fir/beech stands and a stand composition originating from yield tables to simulate forest growth under regional climate change scenarios for a Dutch and a German site.

- The number of days when the tree water demand exceeded the soil water supply was higher for Douglas-fir than for beech. After 45 simulation years the proportion of basal area covered by beech increased from one to seven percent. Beech's competitive strength is mainly explained by the fine root biomass distributions and is highest under the historic climate and the driest climate change scenarios. Higher net primary production (NPP) under warmer/wetter climate but decreased NPP under warmer/drier conditions confirms Douglas-fir's high sensitivity to limited water supply.

- Simulated climate change does not substantially alter the interaction of the two species but the drought-stressed trees are more susceptible to insects or pathogens. The concept of complementary water use highlights the importance of mixed forest for climate change adaptation.
\end{abstract}

\section{INTRODUCTION}

In recent decades, the focus of European forest management has changed from mono-specific and productionoriented forests towards mixed forests with special emphasis on multifunctionality. Although currently a rare forest type, silvicultural incentives to increase the area of Douglasfir (Pseudotsuga menziesii) / beech (Fagus sylvatica) mixed forests are increasing in several Central European regions: either through conversion of former Douglas-fir plantations or through an insertion of Douglas-fir into deciduous production forests. The use of Douglas-fir in European forestry is restricted to the 'coastal' variety (var. viridis) which has substantially higher growth rates than the 'interior' variety (var. glauca) but is less drought-tolerant and susceptible to late frosts (Hermann and Lavender, 1999). Beech constitutes a large part of the potential natural vegetation in temperate $\mathrm{Eu}$ rope but the actual forest area covered by beech is comparably small and limited by historical forest management.

The evidence for climate change and its impacts on forest ecosystems have moved to the centre of interest of forest

*Corresponding author: reyer@pik-potsdam.de science (Aber et al., 2001). Dendroecological studies report that summer precipitation influences the increment of Douglas-fir in lowland, western Poland (Feliksik and Wilczynski, 2004) whereas radial growth of beech at low altitudes in continental climate (Dittmar et al., 2003) and in coastal climate (van der Werf et al., 2007) appears to be relatively insensitive to summer water shortage. In a central European context we define drought as a day or a sequence of days where the plant water demand exceeds plant available water. Specifically for Douglas-fir in the Netherlands, Tiktak and Bouten (1994) simulated up to $31 \%$ reduction of transpiration by drought in the driest years of the period 1960-1990 and large stand-level experiments by de Visser et al. (1994) revealed that Douglasfir trees in the Netherlands were not growing under optimal water conditions. At the background of a changing climate and negative responses of trees to drier conditions, the competition for water is a major concern, as it may alter competition and thus stand dynamics in mixed stands.

The available water can determine the growth of trees (Bréda et al., 2006). A tree's water status depends on its access to soil water and its ability to transport this water to the leaves. The rooting depth, fine root biomass amount and distribution, and the water uptake efficiency of fine roots (number 
of fine root branches and tips) characterise the access to soil water of a species (Bréda et al., 2006). During the absorption of $\mathrm{CO}_{2}$, when the tree's stomates are wide open, the tree inevitably loses water through transpiration. In water-limited situations, the tree minimises such transpirational water loss by reducing the stomatal conductance. This balance between maximising growth (i.e. uptake of $\mathrm{CO}_{2}$ and photosynthesis) and reducing water loss contribute to the competitive strength of a tree species.

In mixed forests, the fine root biomass distribution of an individual species differs from those found in mono-specific forests of the same species. Beech is known to have a higher total fine root biomass $(<3 \mathrm{~mm})$ than other temperate tree species (Leuschner and Hertel, 2003) and a high belowground competitive capacity, as it actively occupies soil strata less occupied by its competitors in mixed systems (Bolte and Villanueva, 2006; Schmid, 2002). Hendriks and Bianchi (1995) examined root density and root biomass in Douglas-fir/beech mixed forests in the Netherlands and concluded that despite domination by Douglas-fir in the aboveground biomass, beech was prevailing in the below-ground biomass and beech roots dominated in deeper soil layers. Similar results have been found for forests with a Norway spruce (Picea abies) and beech mixture (Schmid, 2002; Bolte and Villanueva, 2006). Apparently, beech has the capability to withstand phases of domination, compensate for a lesser proportion of above-ground biomass growth with enhanced below-ground biomass growth and in doing so partly reverse the domination.

The demand to understand and predict such dynamics of mixed forests and to assess the impact of changing environmental conditions challenges forest modelling approaches: instead of mono-specific, even-aged plantations under constant environmental conditions, complex mixed-forests under changing environmental conditions need to be modelled (Burkhart and Tham, 1992). Process-based forest models enable assessments and planning of forest growth and yield but are also applied to simulate stand structure, competition, succession and other stand dynamics under changing environmental conditions and allow experiments that could not be carried out otherwise (Mäkelä et al., 2000a).

Bartelink (1998) developed a model for Douglas-fir/beech mixed stands but focused on competition for light and stable environmental conditions. We consider an even-aged, twospecies mixture which is artificially constructed from monospecies yield tables of beech and Douglas-fir (Jansen et al., 1996) for methodological reasons: it is a simple mixed forest type compared to uneven-aged mixed forests with more than two species and allows analysing competition under different climates in a two-species mixture. Furthermore, there are no suitable single-tree, long-term observations of Douglasfir/beech mixed forests available. Recent trends in conversions of Douglas-fir plantations and discussions about an increased share of Douglas-fir in mixed forests for wood production however require a more detailed analysis of this mixture. So far, no studies have evaluated how drier and warmer climatic conditions influence Douglas-fir/beech mixed stands and how reduced soil water availability might affect their growth. Therefore, the objective of this study is to analyze the effects of a drier and warmer climate on inter-specific competition in a managed Douglas-fir/beech mixed forest using a process-based forest model. Two specific research questions emerge:

1. How does a drier and warmer climate influence the drought experienced by Douglas-fir and beech? We expect that beech will tolerate droughts better than Douglas-fir under a drier and warmer climate. In this sense, we quantified the drought as perceived by a species as the number of days where the water demand is higher than the water supply.

2. Which of the two species is more competitive under a drier and warmer climate? We predict that beech will be more competitive than Douglas-fir under a drier and warmer climate. Under such climate change, we therefore expect that the relative biomass accumulation in the mixed forest stand will increase in beech and decline in Douglas-fir, compared to current conditions.

\section{MATERIALS AND METHODS}

We simulated the development of Douglas-fir/beech mixed forests artificially constructed from yield tables under different climate change scenarios. Therefore, we introduce the two study sites (Sect. 2.1) and present the forest model 4C, the input data, the model adjustments (Sect. 2.2) and finally the simulation design (Sect. 2.3).

\subsection{Study sites}

The two study sites are the Speulderbos (wetter climate, ortic podsol) in the province Gelderland, the Netherlands (Tiktak and Bouten, 1990; Tiktak et al., 1988) and Freienwalde (drier climate, haplic podsol) in Brandenburg, Germany (Riek and Stähr, 2004) (Tab. I; and supplementary, Fig. $S 1^{1}$ ).

\subsection{The forest model $4 \mathrm{C}$}

We simulated forest dynamics using the forest model 4C (FORESEE - FORESt Ecosystems in a changing Environment), which was designed to model the impact of environmental change on forest ecosystems (Bugmann et al., 1997; Lasch et al., 2005; Suckow et al., 2001). 4C is based on water, nutrient and carbon fluxes between the soil, plants and the atmosphere (Fig. S2 ${ }^{1}$ ). Climate, atmospheric $\mathrm{CO}_{2}$ concentration and nitrogen deposition from real data sets or scenarios drive plant processes such as photosynthesis and growth allocation according to ecophysiological principles (Bugmann et al., 1997; Suckow et al., 2001). The 4C photosynthesis submodel (Haxeltine and Prentice, 1996a) includes a $\mathrm{CO}_{2}$ fertilization response and the unstressed stomatal conductance operates more efficiently under elevated $\mathrm{CO}_{2}$. Thus, increased atmospheric $\mathrm{CO}_{2}$ has a positive effect on growth. Furthermore, 4C includes detailed soil and management submodels. The physical and chemical soil processes are spatially and temporally discrete and the soil is divided into layers and simulated according to the parameterization from measured soil profile data.

\footnotetext{
${ }^{1}$ Supplementary material available online only at www.afs-journal. org.
} 
Table I. Characteristics of the Speulderbos and Freienwalde study sites. Precipitation and temperature are mean annual values for the period 1958-2002. The soil information has been aggregated from Tiktak et al. (1988); Tiktak and Bouten (1990) for the Speulderbos and from Riek and Stähr (2004) for Freienwalde.

\begin{tabular}{lccccccccc}
\hline Stand & Coordinates & Region & $\begin{array}{c}\text { Precipitation } \\
(\mathrm{mm})\end{array}$ & $\begin{array}{c}\text { Temperature } \\
\left({ }^{\circ} \mathrm{C}\right)\end{array}$ & $\begin{array}{c}\text { Soil type } \\
\text { pH }\end{array}$ & $\begin{array}{c}\text { Soil depth }^{a} \\
(\mathrm{~cm})\end{array}$ & Soil texture $^{a}$ Soil layers $^{a}$ \\
\hline Speulderbos & $52.25 \mathrm{~N} ; 5.68 \mathrm{E}$ & Gelderland (NL) & 888.9 & 9.6 & Ortic podsol & 4.0 & 309 & Silty sand & 16 \\
Freienwalde & $52.52 \mathrm{~N} ; 14.00 \mathrm{E}$ & Brandenburg (GER) & 523.4 & 8.8 & Haplic podsol & 3.9 & 304 & Loamy sand & 14 \\
\hline
\end{tabular}

${ }^{a}$ As parameterised in $4 \mathrm{C}$.

The water content of each layer is estimated as a function of soil parameters, air temperature, and stand precipitation. The net stand precipitation (i.e. throughfall) percolates from one soil layer to the next soil layer according to a percolation parameter depending on soil texture. Soil evaporation up to a certain depth and water uptake by roots in each soil layer are subtracted. In $4 \mathrm{C}$ cohorts of trees compete for light, water and nutrients (Bugmann et al., 1997). Every cohort features amongst others specific values for fine root, foliage, and stem biomass. A large number of species-specific parameters such as maximum age, wood density, senescence rates of organs and specific leaf area derived from intensive literature studies steer the physiological processes and the development of each species. When the transpiration demand of a cohort exceeds the plant available water (i.e. above the wilting point) in the soil, the canopy conductance and ultimately the net primary production (NPP) of that cohort is reduced according to Haxeltine and Prentice (1996b). This reduction of the NPP corresponds to a partial closure of the stomata and results in a reduction of growth. In the soil model, the amount of precipitation and the percolation rate regulate the water supply $\left(\mathrm{w}_{\text {sup }}\right.$ in $\left.\left(\mathrm{mm} \mathrm{cohort}^{-1}\right)\right)$ in the different soil layers. The water uptake of each cohort depends on its water demand and the available water in the soil layers which is proportional to a cohort's relative share of fine roots in each soil layer. A cohort's water demand $\left(\mathrm{w}_{\mathrm{dem}}\right.$ in $\left(\mathrm{mm}\right.$ cohort $\left.\left.{ }^{-1}\right)\right)$ depends on the potential evapotranspiration, the interception evaporation and the unstressed stomatal conductance. The equations for calculating these variables do not use species-specific parameters. Species-specific parameters determine the foliage biomass, the leaf area index and the leaf respiration of each species but primarily the water demand of Douglas-fir and beech depends on their share of the canopy. Thus, the most important and directly relevant species-specific difference in parameterization of drought $\left(W_{\mathrm{S}}\right)$ is the species-specific fine root biomass distribution (see Sect. 2.2.3). $W_{\mathrm{S}}$ can be calculated for every cohort on a daily basis, as a ratio of water supply and water demand:

$$
W_{\mathrm{S}}=\frac{\mathrm{W}_{\text {sup }}}{\mathrm{W}_{\mathrm{dem}}}
$$

Daily drought occurs, when $W_{\mathrm{S}}<1$. On these days, the lack of water reduces the stomatal conductance and hence the production. A sensitivity analysis of $4 \mathrm{C}$ has been performed in earlier studies (Schaber, Schaber1998, unpublished report; Kint et al., 2009).

\subsubsection{Adjustment of the height growth formulation of Douglas-fir}

The height growth algorithm in 4C was developed by Korol et al. (1995) and tested by Lindner et al. (1997) and depends on a function of the growth in foliage mass $\left(M_{f}\right.$ in ( $\mathrm{kg}$ dry mass)) and the relative irradiance in the crown of the cohort under consideration. The height growth rate $g_{r}\left(\mathrm{~cm} \mathrm{y}^{-1}\right)$ is a function of crown architecture of free growing trees and acceleration of crown height growth by intracanopy shading:

$$
\begin{aligned}
& a_{\mathrm{h}}=\frac{d H}{d M_{\mathrm{f}}}=\frac{-a \cdot b \cdot M_{\mathrm{f}}^{\mathrm{b}-1}}{\left(M_{\mathrm{f}}^{\mathrm{b}}+c\right)^{2}} \\
& g_{\mathrm{r}}=a_{\mathrm{h}}+a_{\mathrm{h}}\left(\frac{1}{\max \left(t_{\mathrm{c}}(m), 0.25\right)}-1\right) .
\end{aligned}
$$

Where $H(\mathrm{~cm})$ is height and $a, b$ and $c$ are species-specific, dimensionless parameters. $I_{\mathrm{c}}(\mathrm{m})(\%)$ is the relative light intensity at the top of the canopy layer $\mathrm{m}$ of cohort $\mathrm{c}$. In a preliminary analysis, Douglas-fir showed a strong reaction to the relative irradiance (results not shown). Therefore, the definition of $I_{\mathrm{c}}(\mathrm{m})$ as the relative light intensity in the upper third of the crown of a cohort instead of the top layer of the canopy of a cohort was introduced for Douglas-fir. This accounts for a different light interception of Douglas-fir's pyramidal crown shape, whereas beech's spherical crown shape conforms better to the cylindrical crown shape used in $4 \mathrm{C}$ and thus the height growth formulation for beech remained unchanged. This adjustment provided less light for Douglas-fir trees, increased their height growth and improved the simulation of the height growth (results not shown).

\subsubsection{Input data}

\subsubsection{Soil data}

The Freienwalde soil was parameterized from the profile 'Johannisberger Tieflehm-Fahlerde' (Riek and Stähr, 2004). The Speulderbos soil data result from earlier studies in the area (Tiktak and Bouten, 1990; Tiktak et al., 1988). Table I summarizes the main characteristics of the two soils. We assumed ample nitrogen availability for both soils to reduce the effect of site productivity and other differences in the parameterisation of the two soils. Thus, merely the effect of soil water availability limits the photosynthesis.

\subsubsection{Stand data and management routine}

The mixed stand used for the analysis was an artificially constructed stand from yield table data (Jansen et al., 1996). The stem number, basal area (BA) and volume from a mono-specific, fullystocked, medium-productive stand of beech and Douglas-fir respectively were divided by two. We then combined these stands to produce the stand values of the mixed stand (Tab. II). The resulting stand does not consist of equal proportions of the two species since Douglas-fir features a higher basal area in the mono-specific stand of the yield table and therefore also covers a higher proportion of 
Table II. Stand characteristics of the mixed stand constructed from yield tables after Jansen et al. (1996). The first two lines indicate the individual contribution of each species to the Douglas-fir/beech mixture which is displayed in the third line and was initialised in $4 \mathrm{C}$ for the Speulderbos (NL) and Freienwalde (GER).

\begin{tabular}{lccccccc}
\hline Species & Age & $\begin{array}{c}\mathrm{N} \\
\left(\mathrm{ha}^{-1}\right)\end{array}$ & $\begin{array}{c}\text { DBH } \\
(\mathrm{cm})\end{array}$ & $\begin{array}{c}\text { Height } \\
(\mathrm{m})\end{array}$ & $\begin{array}{c}\text { Basal area } \\
\left(\mathrm{m}^{2} \mathrm{ha}^{-1}\right)\end{array}$ & $\begin{array}{c}\text { Stem volume } \\
\left(\mathrm{m}^{3} \mathrm{ha}^{-1}\right)\end{array}$ & $\begin{array}{c}\text { Stand } \\
\text { productivity }\end{array}$ \\
\hline Douglas-fir & 20 & 866 & 12.4 & 10.8 & 10.44 & 62.5 & "Groeiklasse 12" \\
Beech & 20 & 2157 & 6.0 & 5.8 & 6.19 & 18.0 & "Groeiklasse 8" \\
Douglas-fir/beech & 20 & 3023 & 9.2 & 8.3 & 16.62 & 80.5 & - \\
\hline
\end{tabular}

Table III. Main characteristics of the climate change scenario realisations and the historic climate for the Speulderbos (NL) and Freienwalde (GER). The Dutch climate data were provided by the Royal Dutch Meteorological Institute and downscaled at Wageningen University and the German data set is from the German Weather Service and downscaled at Potsdam Institute for Climate Impact Research (PIK). Temperature and precipitation are mean annual values from 1958-2002 for the historic climate and from 2000-2044 for the climate change scenario realisations. The column ' $\mathrm{CO}_{2}$ ' provides the rise in atmospheric $\mathrm{CO}_{2}$-concentration associated with the respective climate change scenario realisation or the historic climate.

\begin{tabular}{lccccc}
\hline Location & Scenario & $\begin{array}{c}\text { Temperature } \\
\left({ }^{\circ} \mathrm{C}\right)\end{array}$ & $\begin{array}{c}\text { Precipitation } \\
(\mathrm{mm})\end{array}$ & $\mathrm{CO}_{2}$ & Type \\
\hline Speulderbos & $\mathrm{H}$ & 9.6 & 888.9 & Mauna Loa $^{a}$ & Historic \\
Speulderbos & $\mathrm{G}$ & 10.6 & 903.2 & $\mathrm{~B}^{b}$ & Scenario \\
Speulderbos & $\mathrm{G}+$ & 10.8 & 882.6 & $\mathrm{~B}^{b}$ & Scenario \\
Speulderbos & $\mathrm{W}$ & 11.1 & 917.8 & $\mathrm{~A}^{b}$ & Scenario \\
Speulderbos & $\mathrm{W}+$ & 11.5 & 877.8 & $\mathrm{~A}^{b}$ & Scenario \\
Freienwalde & FRWH & 8.8 & 523.4 & $\mathrm{Mauna} \mathrm{Loa}^{a}$ & Historic \\
Freienwalde & FRW1 & 10.1 & 523.3 & $\mathrm{~A} 1 B^{b}$ & Scenario \\
Freienwalde & FRW2 & 10.1 & 522.2 & $\mathrm{~A} 1 B^{b}$ & Scenario \\
Freienwalde/ Speulderbos & FRW3/FRW3 & 10.1 & 518.6 & $\mathrm{~A} 1 B^{b} / \mathrm{A}^{b}$ & Scenario \\
\hline
\end{tabular}

${ }^{a}$ Associated rise in atmospheric $\mathrm{CO}_{2}$-concentration according to the Mauna Loa observatory.

${ }^{b}$ Associated rise in atmospheric $\mathrm{CO}_{2}$-concentration according to SRES storylines (Nakicenovic et al., 2000).

the BA in the mixed stand. Real Douglas-fir/beech mixed forests in the Netherlands are not balanced either: Similarly to the constructed stands, Douglas-fir dominates (Bartelink, 1998). The same stand composition was assumed for the two studied sites (Tab. II). This simple approach substitutes missing long-term single-tree data from mixed forests and allows simulating exactly the same stand composition at the two study sites under different climatic conditions.

We applied the same management routine in all model runs in order to mimic the development of real managed forests in the Speulderbos and Freienwalde. The management routine reduces the stem numbers to the values prescribed by the yield table through thinning from above. Thus, all simulations featured equal stem densities and were exclusively controlled by management so that no natural mortality occurred due to low light availability.

\subsubsection{Climate and climate change scenario data}

The Royal Dutch Meteorological Institute (KNMI) provided the historical climate data for the period 1958-2008 of the 'de Bilt' weather station located around $35 \mathrm{~km}$ south-west of the Speulderbos in daily resolution. We smoothed an orographic effect from de Bilt to the Speulderbos by replacing the precipitation data of de Bilt with precipitation data from Putten (ca. $3 \mathrm{~km}$ from the Speulderbos). For Freienwalde, we used historical climate data for the 'SchiffsmühleNeutornow' meteorological station of the German Weather Service (DWD) from the Potsdam Institute for Climate Impact Research (PIK) climate database for the period 1958-2002 in daily resolution.
This precipitation station is located $34 \mathrm{~km}$ from Freienwalde and climate parameters other than precipitation have been interpolated to that location by the PIK.

We used regional climate change scenarios to simulate possible effects of future climate change (Gerstengarbe and Werner, 2005; van den Hurk et al., 2006) on the mixed forests. The utilization of different climate change scenarios and scenario realisations covering a wide array of possible future climatic conditions accounts for the uncertainty associated with climate change scenarios. The climate change scenario realisations for the two regions were derived from simulations of Global Circulation Models and differ from the historical climate of the two study sites mainly in precipitation and temperature. The increases in atmospheric $\mathrm{CO}_{2}$-concentration associated with each climate change scenario realisation do not differ substantially until 2050 (Nakicenovic et al., 2000). For Freienwalde, the PIK provided three climate change scenario realisations. They originate from an ECHAM-5 model run of the Max-Planck-Institute for Meteorology (Hamburg) according to the SRES scenario A1B and have been downscaled for the Elbe-river watershed (Gerstengarbe and Werner, 2005). The climate change scenario realisations for Freienwalde are characterised by an increase of mean annual temperature by $1.5 \mathrm{~K}$ until 2060 and feature different amounts of annual precipitation as well as higher precipitation in winter and lower precipitation in summer (Tab. III). This results in distinct climatic water balances (CWB) (Fig. 1). The CWB equals precipitation minus potential evapotranspiration which was calculated after Turc-Ivanov. This indicates when potential drought for the plants occurs. For the Netherlands, the four climate change scenarios of the $\mathrm{KNMI}(\mathrm{G}, \mathrm{G}+, \mathrm{W}$, and $\mathrm{W}+)$ for the 

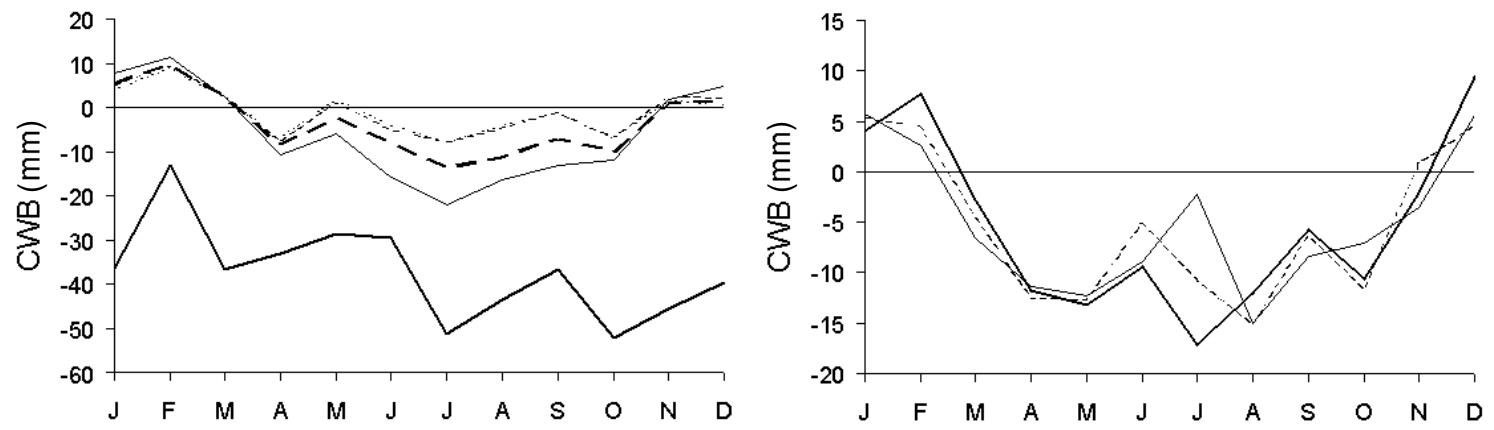

Figure 1. Deviation of the mean monthly climatic water balance (CWB equals precipitation minus potential evapotranspiration in (mm)) over the simulation period (2000-2044) from the historic climate (1958-2002), zero line)) for the Speulderbos, The Netherlands (left) and Freienwalde, Germany (right). For the Speulderbos: thick line $=$ FRW3 $*$, thin line $=\mathrm{W}+$, thick dashed line $=\mathrm{G}+$, thin dashed line $=\mathrm{W}$, dotted line $=$ G. For Freienwalde: thick line $=$ FRW3, thin line $=$ FRW2, dashed line $=$ FRW1.

period 2009-2050 (van den Hurk et al., 2006) represent possible climate trajectories. The scenarios $\mathrm{G}$ and $\mathrm{G}+$ feature a temperature increase of $1 \mathrm{~K}$ and increasing summer precipitation. The scenarios $\mathrm{W}$ and $\mathrm{W}+$ show $2 \mathrm{~K}$ increase in temperature and a reduction in summer precipitation (Tab. III). The KNMI 'Transformator programme' (http://www.knmi.nl/) enabled the downscaling of the Dutch climate change scenarios to regional-scale climate change scenario realisations. The driest scenario for Freienwalde (henceforth 'FRW3') was also used for the Speulderbos simulations (abbreviated as 'FRW3*') to simulate very dry conditions in the Netherlands. It accounts for a temperature increase of $0.5 \mathrm{~K}$ but a precipitation reduction of more than $40 \%$ which results in a drastic decrease of the CWB (Fig. 3). The data have been checked for homogeneity and completeness at PIK and Wageningen University.

\subsubsection{Integration of a species-specific fine root biomass distribution}

The empirical literature on fine root biomass distributions in mixed forests from different regions in Central Europe shows that beech fine roots grow into deeper soil layers and have a higher fine root biomass in deeper soil layers (Bolte and Villanueva, 2006; Hendriks and Bianchi, 1995; Schmid, 2002). We initialised the species-specific fine root biomass distribution of beech and Douglasfir that Hendriks and Bianchi (1995) found in the Speulderbos in $4 \mathrm{C}$ and assumed it to be representative for Douglas-fir/beech mixed stands in the two study regions (Fig. 2). This accounts for different fine root biomass distributions in mixed stands rather than in monospecific stands. Henceforth, this implementation of a species-specific fine root biomass distribution corresponds to a realistic formulation of below-ground conditions in mixed stands.

\subsection{Simulation design}

\subsubsection{Model verification}

To assess the validity of the results, we carried out a model verification before starting the simulation experiments with climate change scenario realisations. We ran the model for the mixed stand on the Speulderbos and Freienwalde sites and compared the simulation results to the yield table values. Although the yield table values can only

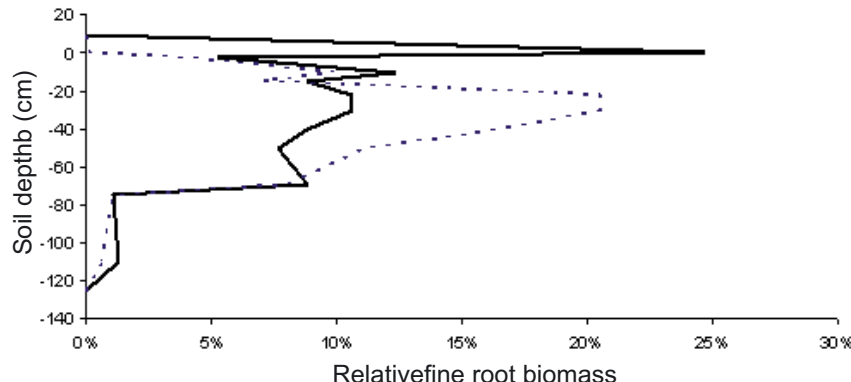

Figure 2. Species-specific relative fine root biomass distribution for beech (dashed line) and Douglas-fir (full line) after Hendriks and Bianchi (1995) for a Douglas-fir/beech mixed stand as initialised for the Speulderbos soil. Note that the Freienwalde soil differs slightly in the soil depths but not in the pattern of fine root biomass distribution.

partly substitute missing single-tree long-term measurements, the deviation of the simulated diameter at breast height (DBH), height, density and stem volume from them helps to assess the accuracy of the simulations.

\subsubsection{Simulation of drought and inter-specific competition under climate change}

We simulated the mixed stand (see Sect. 2.2.2) on the Freienwalde and Speulderbos sites under the described climate change scenario realisations and the historical climates (Tab. III). In order to assess the influence of climate change on the drought experienced by the trees in the Douglas-fir/beech mixed forest, the average number of days where drought occurs for the simulation time was calculated from Equation (1) by counting the number of days on which $W_{\mathrm{S}}$ was less than one over the simulation period. This number indicates the average number of days where the stomatal conductance and the tree growth are reduced. Furthermore, the effect of climate change on the inter-specific competition in the Douglas-fir/beech mixed forest was tested in Freienwalde and in the Speulderbos. The basal area of each species in relation to the total stand basal area has proven to be an effective indication of competitive processes (Oosterbaan et al., 1999). Therefore, the proportion of basal area covered by the two species after 45 simulations years was compared to the starting proportions 

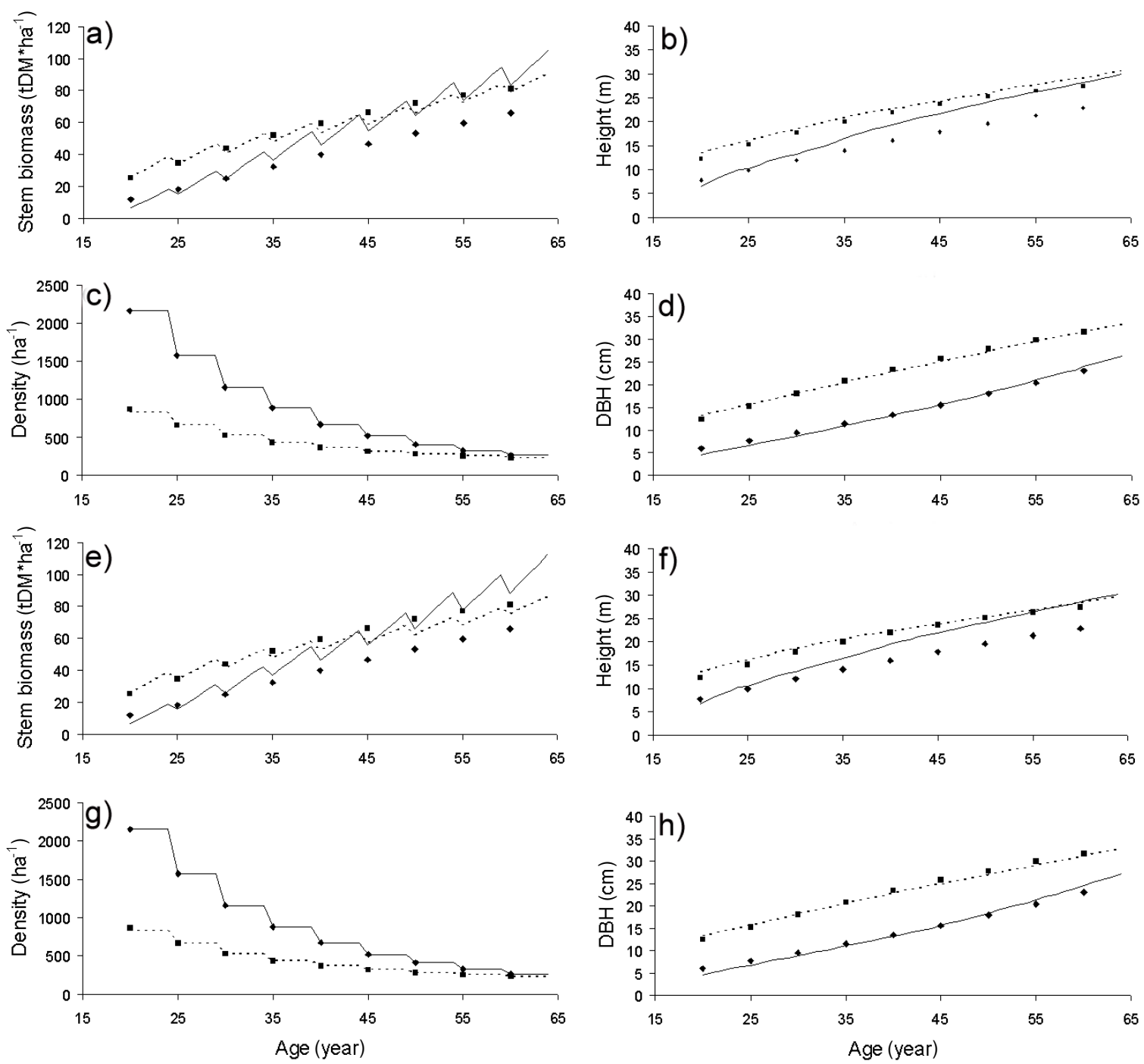

Figure 3. Comparison of simulated and yield table values of stand characteristics of the Douglas-fir/beech mixed stand in the Speulderbos (a-d) and Freienwalde (e-h) (after Jansen et al., 1996). The lines indicate simulated values for Douglas-fir (dashed line) and beech (full line) and the symbols represent yield table values for Douglas-fir (squares) and beech (diamonds).

at the time of initialisation. Additionally, the development of the NPP of beech and Douglas-fir in Freienwalde was analysed for the historical climate and the FRW1 and FRW3 climate change scenario realisations. The simulation experiment lasted 45 years: from 2000-2044 for all climate change scenario realisations (FRW1, FRW2, FRW3, G, $\mathrm{G}+, \mathrm{W}, \mathrm{W}+, \mathrm{FRW} 3 *$ ) and from 1958-2002 for the historical climates (FRWH, H).

\section{RESULTS}

\subsection{Model verification}

The simulated tree numbers were identical with the yield table values (Figs. 3c, 3g). The difference between yield table diameter values and simulated diameters was low (Figs. 3d, 3h), but the height growth of beech was overestimated in all simulations and the simulated values deviated from the yield table values. For Douglas-fir the height growth fitted the yield table values (Figs. 3b, 3f). The stem biomass is closely related to height and diameter and therefore biomass simulation values that diverged from yield table values were explained by imprecise simulations of height growth (Figs. 3a, 3e). However, in general the simulated values followed the same pattern as the yield tables.

\subsection{Influence of climate change on drought experienced by Douglas-fir and beech}

We assessed the effect of a drier and warmer climate on the drought experienced by the two species. The number of days when the cohort water demand exceeded the soil water 


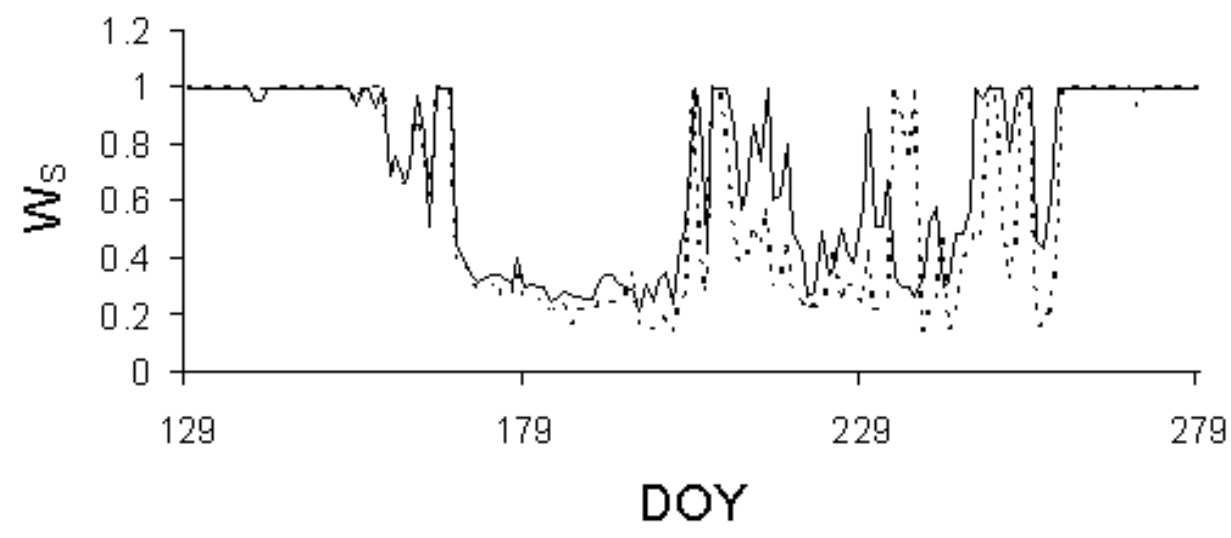

Figure 4. Annual course of the water supply and water demand ratio $\left(W_{\mathrm{S}}\right)$ of beech and Douglas-fir at the Freienwalde site in the year 2010 of the FRW3 scenario realisation with the species-specific fine root biomass distribution. (Full line $=$ beech; dashed line $=$ Douglas-fir; DOY = Day of the year).

supply was higher for Douglas-fir than for beech under most scenario realisations on both sites; the sole exception being an almost equal number of dry days in the historical climate of the Speulderbos (Fig. S3 ${ }^{1}$ ). As an example of an extreme year, Figure 4 displays the annual course of $W_{\mathrm{S}}$ in the extremely dry (291.4 mm of annual precipitation) simulation year 2010 of the FRW3 scenario realisation. In the summer (between days of the year 150-270, i.e. from June to September) the average $W_{\mathrm{S}}$ on the water-limited days in this year $\left(W_{\mathrm{S}}<1\right.$, i.e. $w_{\text {sup }}<$ $w_{\text {dem }}$ ) equalled to 0.48 for beech and 0.38 for Douglas-fir. In this year, both species experienced drought and there was not enough water available for the fine root water uptake to satisfy the water demand in the transpiring canopy and hence stomatal conductance and ultimately growth were reduced.

\subsection{Inter-specific competition under climate change}

In the core of this study we assessed the competition between Douglas-fir and beech under different climate scenario realisations in terms of basal area and NPP. The basal area of the initialised mixed stand consisted of $37 \%$ beech and $63 \%$ Douglas-fir at the age of 20 . After $45 \mathrm{y}$, the proportion of basal area covered by beech increased by $1 \%$ to $7 \%$ in all scenario realisations and the historic climates (Fig. S4 ${ }^{1}$ ). The increase of beech coincided with an equal decrease of basal area covered by Douglas-fir. The increase in the proportion of the basal area covered was highest under the historic climate and the driest scenario realisation (Freienwalde scenario realisations FRWH, FRW3 and Speulderbos scenario realisations $\mathrm{H}, \mathrm{FRW} 3 *$ ). In the warmer but not substantially drier scenario realisations (FRW1, FRW2, G, G+, W, W+) the change was lower. More specifically, the increase in basal area of beech in the historic climate was highest and slightly lower in the driest scenario realisation in Freienwalde whereas the extreme dry scenario realisation showed the highest basal area covered by beech in the Speulderbos (Fig. S4 ${ }^{1}$ ).

The analysis of the simulated NPP in Freienwalde revealed a stronger increase in productivity of beech than of Douglas-fir
(Figs. 5a, 5b).The NPP of beech increased from the historic climate to the FRW1 scenario realisation and was highest under the FRW3 scenario realisation (Fig. 5a). For Douglas-fir, the historic climate showed the lowest NPP and the FRW1 scenario realisation had a higher NPP than the FRW3 scenario realisation (Fig. 5b). The average NPP of both species increased with higher stand age but the increase was less for Douglas-fir than for beech (Fig. 5a). Furthermore, the NPP of both species showed larger variations under the climate change scenario realisations than under the historic climate (Figs. 5a, 5b).

\section{DISCUSSION}

We expected that different fine root distributions would render Douglas-fir more sensitive to dry periods as compared to beech, and that beech therefore would gradually outcompete Douglas-fir under the warmer and drier climate change scenarios. To test these hypotheses, we implemented a speciesspecific fine root biomass derived from a root excavation study (Hendriks and Bianchi, 1995) in the model 4C. The results show that $4 \mathrm{C}$ simulates basal area changes of both species over time accurately, but that the model is less precise for height or biomass in beech. Therefore, we evaluated the dynamics of basal area under different climate change scenario realisations and compared those with dynamics under current climate conditions.

\subsection{Model verification}

The 4C model has been evaluated with volume growth and survival graphs (Mäkelä et al., 2000b) and several studies focussed on the validation of the management (Lasch et al., 2005) and the soil submodel (Suckow et al., 2001). In this study, the simulations of DBH yielded similar values and pattern to those displayed in the yield table which is important for the calculation of a realistic basal area. 

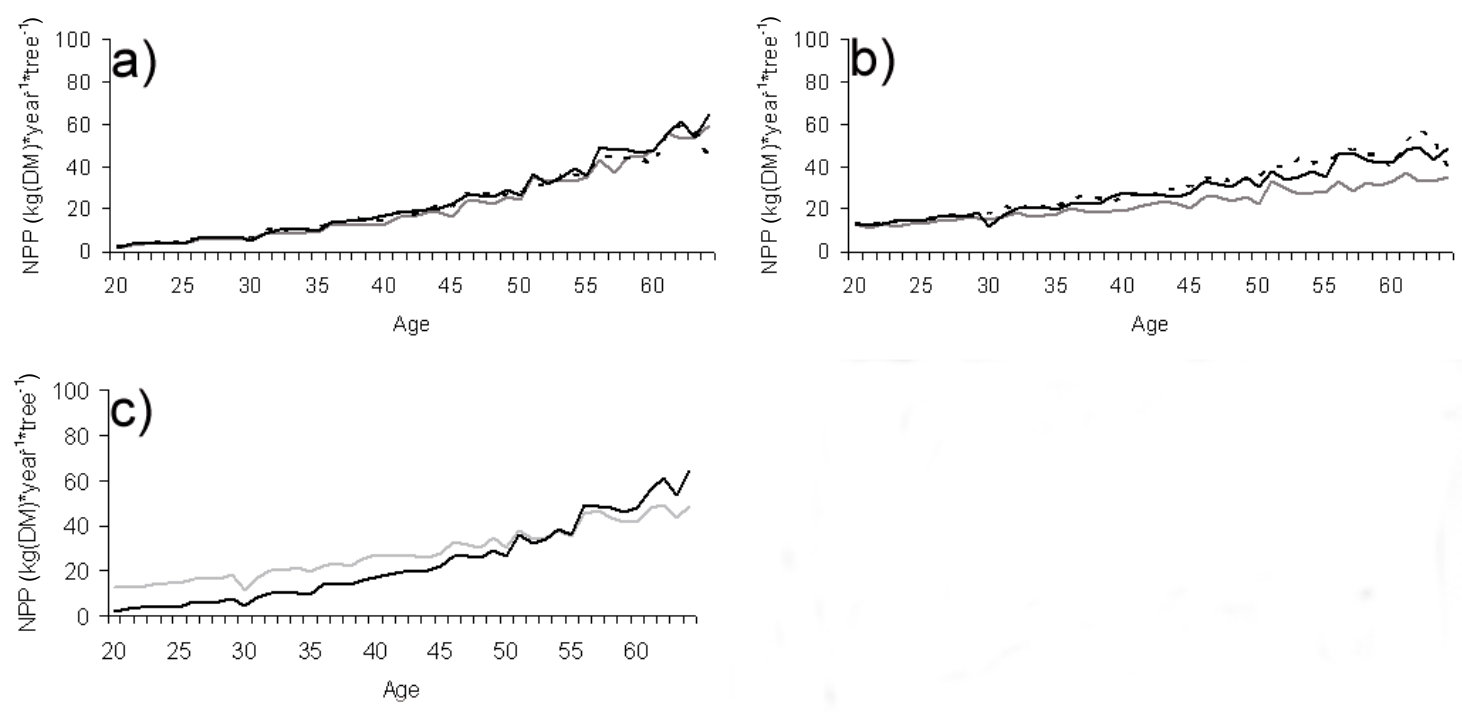

Figure 5. NPP of beech (a) and Douglas-fir (b) in Freienwalde under the historic climate (dark grey line), the FRW1 scenario realisation (dashed line) and the FRW3 scenario realisation (bold line). For a better comparison the NPP of beech and Douglas-fir in the Freienwalde stand under the FRW3 scenario realisation are displayed together in sub-graphic c (light grey line = Douglas-fir; black line $=$ beech).

The simulated height growth was not always congruent with the yield table values. For Douglas-fir, an improved formulation of the height growth function by changing the effect of the irradiance (cf. Sect. 2.2.1) showed a good fit for height growth. For beech however, height growth was overestimated for the following reasons: the beech trees were shorter than the Douglas-fir trees in the beginning of the simulation and may not have received enough light. The formulation of the height growth in equation (3) shows that in shaded conditions, when the denominator approaches its minimum value of 0.25 , the height growth can be four times higher than under an unrestricted light regime, when the denominator would be at its maximum value of one. This explained beech's strong height growth as a response to low light availability in comparison with the height growth predicted from yield tables of mono-specific beech stands. As a consequence of the imprecise height growth simulation, the volume simulations also did not reproduce the yield table values in beech. Basal area was much better predicted for both beech and Douglas-fir and was therefore used as the comparative measure of production and competitive ability of both species under future climate scenarios.

The results of the model verification differed from those of Bartelink (1998), who found that the development of mixed Douglas-fir/beech stands is not linearly related to the initial basal area proportions of the two species and that the two species together perform differently than yield tables from mono-specific stands suggest. In his study, however, Bartelink (1998) only considered competition for light and did not consider species-specific fine root distributions, which may partly explain the good fit for observed and predicted basal area patterns in our simulations. In the following, we therefore focus on our basal area predictions for Douglas and beech in mixed stands under a variety of climate scenarios.

\subsection{Change in drought conditions}

In $4 \mathrm{C}$, drought can be expressed as the number of days with water deficit. The results of the analysis of the number of simulated drought days indicate that Douglas-fir perceived the climate as drier compared to beech, because of the species-specific fine root biomass distribution. Although the climate change scenario realisations increased the NPP of the two species in comparison to the historic climate, the climate change scenarios involved more days on which drought occurred for both species, but in particular for Douglas-fir. The limited soil water availability reduced the NPP in extreme years below the level of the historic climate such as in the year 2010 (i.e. age 30) (Fig. 5). In that year, the stomatal conductance decreased less severely in beech than in Douglas-fir (Fig. 4) and, as a result, NPP decreased more strongly in the latter species (Fig. 5c). This finding is consistent with the hypothesis that beech is more drought-tolerant than Douglas-fir in mixed forests due to the species-specific fine root biomass distribution. Beech maintained its growth rate whereas the growth of Douglas-fir slowed down. Besides the high shade tolerance of beech trees this is another advantage that qualifies beech as a strong competitor in mixed forests. Furthermore, such a rooting strategy shows a complementary use of the site's resources and indicates a positive effect of competition on growth in mixed stands in comparison with mono-specific stands (Burkhart and Tham, 1992; del Río and Sterba, 2009; Kelty and Cameron, 1994). This differentiated functioning of mixed forests highlights their importance for adapting forests and forest management to climate change. The exceptionally strong response to very dry years in both species (Fig. 4) which can affect the growth and competitive strength of tree species for several consecutive years (Lebourgeois, 2007) indicates the importance of extreme years in assessing the sensitivity 
of forests to climate change. Furthermore, there are ecophysiological differences between the two species that may be relevant for growth in dry conditions but not accounted for in 4C: firstly, the version of $4 \mathrm{C}$ used in this study does not feature different responses to vapour pressure deficit. Alternatives for the used evapotranspiration calculation after TurcIvanov that integrate the vapour pressure deficit such as the Penman-Monteith equation are implemented in $4 \mathrm{C}$ and could be applied in a comparative study testing responses to vapour pressure deficit. Secondly, Douglas-fir is less vulnerable to cavitation than beech (Bréda et al., 2006). This can be compensated by higher allocation to sapwood and greater sapwood storage (Stout and Sala, 2003) and thus does not necessarily entail a higher drought tolerance of Douglas-fir. Serious damage from cavitation occurs after several months of drought (Cruiziat et al., 2002) but these are different conditions from those simulated in our analysis.

\subsection{Inter-specific competition under climate change}

Both species were predicted to have a higher productivity under climate change. Beech however always achieved a greater share in the basal area at the stand level (Fig. S4 ${ }^{1}$ ), suggesting that beech is more competitive than Douglas-fir in all cases. Basically, this competitive advantage for beech is attributed to a species-specific fine root biomass distribution penetrating deeper soil layers. While only referring to competition for radiation, Bartelink (1998) suggested that beech would disappear from the mixture. Here, the initialised species-specific fine root biomass according to Hendriks and Bianchi (1995) represents a more realistic below-ground biomass distribution of the two species and suggests an opposite trend with declining proportions of Douglas-fir. Furthermore, this finding confirms the idea of Hendriks and Bianchi (1995) on an above-ground domination of Douglas-fir which reverses itself over the stand development. The photosynthesis of Douglas-fir is reduced by drought, hence beech has a relatively higher NPP and more carbon is allocated to the stem. The slow increase of the NPP of Douglas-fir under the climate change scenario realisations and the historic climates (Fig. 5b) illustrates that Douglas-fir faces less favourable growing conditions than beech.

In order to test the effect of the species-specific fine root biomass, we ran the simulations again but switched the species-specific fine root distribution, associating the initialised Douglas-fir fine root biomass distribution to beech and vice versa. This simple model input change inversed the competition pattern found earlier and Douglas-fir increased in basal area covered whereas beech decreased. This effect gradually increased with warmer and drier climate change scenario realisations (results not shown) and confirms the effect of the species-specific fine root biomass distribution on the inter-specific competition in Douglas-fir/beech mixed forests. However, the model parameterization and simulation set-up do not entail substantial changes in the interaction of beech and Douglas-fir under climate change.

\subsubsection{Effect of higher temperatures}

The results suggest that the competitive strength of beech was highest under the current climate. Under the warmer but not substantially drier conditions (scenario realisations FRW1, FRW2, G, G+ and $\mathrm{W}, \mathrm{W}+$ ) beech was not as competitive as under the historic climate (Fig. S4 ${ }^{1}$ ). In 4C, warmer temperatures increase the productivity through enhanced photosynthesis and longer vegetation periods and have a feedback on the water demand through increased potential evapotranspiration and higher unstressed stomatal conductance. The positive effect of higher temperatures of these scenario realisations was not constrained by a severe reduction in precipitation or even enhanced by higher precipitation, leaving enough water for the two species. Hence these scenario realisations influenced the interaction of Douglas-fir and beech less and the changes in basal area remained below 3\% in Freienwalde and the Speulderbos. In these scenarios, the climatic conditions even improved the competitive status of Douglas-fir to a certain extent in comparison with the historic climates (Fig. S4 ${ }^{1}$ ) and increasing NPP of Douglas-fir explains the small changes in basal area (Fig. 5).

\subsubsection{Effect of higher temperatures and reduced precipitation}

If the temperature increased and the summer precipitation decreased such as indicated by the lower mean CWB in July (Fig. 1) in the scenario realisations FRW3 and FRW3* compared with the historic climate, the proportion of basal area covered by beech increased. Douglas-fir's decreasing NPP under the warmer and drier FRW3 scenario realisation in comparison to the warmer but not drier FRW1 scenario realisation suggests that it is primarily the lower production level of Douglas-fir than the higher productivity of beech that shifts the competition (Fig. 5b). The species-specific fine root distribution and the resulting improved water supply favour beech and disadvantage Douglas-fir. Beech's basal area increased by more than $3 \%$ (Fig. $4^{1}$ ) and a decrease in the CWB of June/July from FRW1 to FRW3, which reflects a changing seasonal distribution of precipitation (Fig. 1), entailed more than $2 \%$ increase in basal area covered by beech. Therefore, only slight decreases in precipitation in the summer may worsen the situation for Douglas-fir in water-limited regions and disable benefits from warmer temperatures (Boisvenue and Running, 2006). This is especially important with regard to projected increases in winter precipitation and decreases in summer precipitation (Gerstengarbe and Werner, 2005). For the generally wetter Speulderbos site, such extremely dry summer conditions only occurred under the drastic climate change scenario FRW3* (Fig. S4 ${ }^{1}$ ).

\subsubsection{Further effects under changing climate}

Although the simulated impact of drought was low and neither of the two species declines beyond a critical level, drought 
contributes to tree death by increasing the predisposition to other disturbances and stressors such as insects, pathogens, or fire (Bréda et al., 2006). Such a higher vulnerability may threaten Douglas-fir in reality, especially since the main insects damaging Douglas-fir (Dendroctonus pseudotsugae and Orgyia pseudotsugae) do not yet occur in Europe but are likely to prosper under future climates (Verkaik et al., 2009). Such amplifying mechanisms are not included in 4C and aggravate the real impact of drier conditions. Additionally, this analysis only accounts for changes in competition of managed stands. In stands that are not regulated through management, the stem densities are higher, the competition for water thus more intense and this increases the effect of climate change on competition. However, Douglas-fir stands are managed for wood production and show a structure and a biogeochemistry distinct from unmanaged stands (Hall and Marchand, 2010) and since we were interested in the response of managed forests to climate change, we only considered managed stands.

\section{CONCLUSION}

In this model analysis with 4C two hypotheses were tested and confirmed: (1) Beech experiences less drought and (2) is more competitive than Douglas-fir under all climate change scenario realisations. The beech's competitive strength in the model is related to improved drought tolerance resulting from high fine root distribution in lower soil layers. The simulated climate changes neither entail a decline of either of the two species nor substantially change their interaction. In reality however, the drought-stressed trees can be more susceptible to insects or pathogens. This and other synergistic impacts of climate change-related phenomena may amplify or override the mere effect of increasing temperatures and decreasing precipitation but are yet to be modelled. The complementary use of rooting space in mixed forests highlights the importance of mixed forest in adapting forest management and forest ecosystems to climate change. Further research may determine if growing tree species in mixed forests enables their maintenance in areas where their distribution as a monoculture is questioned under future climatic conditions, clarify the interspecific competition of tree species by studying rooting depth and water relations in mixed stands and improve the mechanistic modelling of mixed stands under changing environmental conditions.

Acknowledgements: The research reported here was part of a M.Sc.-thesis at Wageningen University and under the Erasmus Mundus M.Sc.-programme "European Forestry". CR received financial support from the German National Merit Foundation and the Erasmus Mobility Programme. We would like to thank our colleague F. Suckow for implementing the species-specific fine root biomass distribution tool in $4 \mathrm{C}$, J. Bessembinder for help with the Dutch climate change scenarios, M. Gutsch, two anonymous reviewers and D.E. Hibbs for valuable comments on an earlier version of the manuscript.

\section{REFERENCES}

Aber J., Neilson R.P., McNulty S., Lenihan J.M., Bachelet D., and Drapek R.J., 2001. Forest processes and global environmental change: Predicting the effects of individual and multiple stressors. Bioscience 51: 735-751.

Bartelink H., 1998. Simulation of growth and competition in mixed stands of Douglas-fir and beech. Ph.D. thesis Wageningen University, Wageningen, The Netherlands.

Boisvenue C. and Running S.W., 2006. Impacts of climate change on natural forest productivity - evidence since the middle of the 20th century. Glob. Change Biol. 12: 862-882.

Bolte A. and Villanueva I., 2006. Interspecific competition impacts on the morphology and distribution of fine roots in European beech (Fagus sylvatica L.) and Norway spruce (Picea abies (L.) Karst.). Eur. J. For. Res. 125: 15-26.

Breda N., Huc R., Granier A., and Dreyer E., 2006. Temperate forest trees and stands under severe drought: a review of ecophysiological responses, adaptation processes and long-term consequences. Ann. For. Sci. 63: 625-644.

Bugmann H., Grote R., Lasch P., Lindner M., and Suckow F., 1997. A new forest gap model to study the effects of environmental change on forest structure and functioning. In: Mohren G.M.J., Kramer K., and Sabaté S. (Eds.), Impacts of global change on tree physiology, Kluwer Academic Publishers, Dordrecht, The Netherlands.

Burkhart H. and Tham A., 1992. Predictions from growth and yield models of the performance of mixed-species stands. In: Cannel M., Malcolm D., and Robertson P. (Eds.), The ecology of mixed-species stands of trees, Blackwell, Oxford.

Cruiziat P., Cochard H., and Améglio T., 2002. Hydraulic architecture of trees: main concepts and results. Ann. For. Sci. 59: 723-753.

Del Río M. and Sterba H., 2009. Comparing volume growth in pure and mixed stands of Pinus sylvestris and Quercus pyrenaica. Ann. For. Sci. 66: 502.

De Visser P.H.B., Beier C., Rasmussen L., Kreutzer K., Steinberg N., Bredemeier M., Blanck K., Farrell E.P., and Cummins T., 1994. Biological response of five forest ecosystems in the EXMAN project to input changes of water, nutrients and atmospheric loads. For. Ecol. Manage. 68: 15-29.

Dittmar C., Zech W., and Elling W., 2003. Growth variations of Common beech (Fagus sylvatica L.) under different climatic and environmental conditions in Europe - a dendroecological study. For. Ecol. Manage. 173: 63-78.

Feliksik E. and Wilczynski S., 2004. Dendroclimatological regions of Douglas fir (Pseudotsuga menziesii Franco) in western Poland. Eur. J. For. Res. 123: 39-43.

Gerstengarbe F. and Werner P., 2005. Simulationsergebnisse des regionalen Klimamodells STAR. In: Wechsung F., Becker A., and Gräfe P. (Eds.), Auswirkungen des globalen Wandels auf Wasser, Umwelt und Gesellschaft im Elbegebiet, Weißenseeverlag, Berlin, Germany.

Hall S.J. and Marchand P.J., 2010. Effects of stand densitiy on ecosystem properties of subalpine forests in the southern Rocky Mountains, USA. Ann. For. Sci. 67: 102.

Haxeltine A. and Prentice I.C., 1996a. A general model for the light-use efficiency of primary production. Funct. Ecol. 10: 551-561.

Haxeltine A. and Prentice I.C., 1996b. BIOME3: An equilibrium terrestrial biosphere model based on ecophysiological constraints, resource availability, and competition among plant functional types. Glob. Biogeochem. Cycles 10: 693-709.

Hendriks C.M.A. and Bianchi F., 1995. Root density and root biomass in pure and mixed forest stands of Donglas-fir and Beech. Neth. J. Agric. Sci. 43: 321-331.

Hermann R.K. and Lavender D.P., 1999. Douglas-fir planted forests. New For. 17: 53-70. 
Jansen J., Sevenster J., and Faber P., 1996. Obsprengsttabellen voor belangrijke boomsorten in Nederland. Landbouwuniversiteit Wageningen, Wageningen, The Netherlands.

Kelty M. and Cameron I., 1994. Ecological principles of production differences between monociultures and mixtures. In: Costa M.P.D. and Preuhsler T. (Eds.), Mixed stands: research plots, measurements and results, models, Instituto Superior de Agronomia, Lisboa, Portugal.

Kint V., Lasch P., Lindner M., and Muys B., 2009. Multipurpose conversion management of Scots pine towards mixed oak-birch stands-A long-term simulation approach. For. Ecol. Manage. 257: 199-214.

Korol R.L., Running S.W., and Miller K.S., 1995. Incorporating intertree competition into an ecosystem model. Can. J. For. Res. 25: 413-424.

Lasch P., Badeck F.W., Suckow F., Lindner M., and Mohr P., 2005. Model-based analysis of management alternatives at stand and regional level in Brandenburg (Germany). For. Ecol. Manage. 207: 59-74.

Lebourgeois F., 2007. Climatic signal in annual growth variation of silver fir (Abies alba Mill.) and spruce (Picea abies Karst.) from the French permanent plot network (RENECOFOR). Ann. For. Sci. 64: 333-343.

Leuschner C. and Hertel D., 2003. Fine root biomass of temperate forests in relation to soil acidity and fertility, climate, age and species. Prog. Bot. 64: 405-438.

Lindner M., Sievanen R., and Pretzsch H., 1997. Improving the simulation of stand structure in a forest gap model. For. Ecol. Manage. 95: 183-195.

Mäkelä A., Landsberg J., Ek A.R., Burk T.E., Ter-Mikaelian M., Agren G.I., Oliver C.D., and Puttonen P., 2000a. Process-based models for forest ecosystem management: current state of the art and challenges for practical implementation. Tree Physiol. 20: 289-298.

Mäkelä A., Sievanen R., Lindner M., and Lasch P., 2000b. Application of volume growth and survival graphs in the evaluation of four processbased forest growth models. Tree Physiol. 20: 347-355.

Nakicenovic N., Alcamo J., Davis G., Vries B.D., Fenhann J., Gaffin S., Gregory K., Grübler A., Jung T., Kram T., Rovere E.L., Michaelis L., Mori S., Morita T., Pepper W., Pitcher H., Price L., Riahi K., Roehrl A., Rogner H., Sankovski A., Schlesinger M., Shukla P., Smith S., Swart R., Rooijen S.V., Victor N., and Dadi Z., 2000. IPCC Special Report Emission Scenarios. Cambridge University Press, Cambridge, United Kingdom.

Oosterbaan A., Berg C.V.D., and Olsthoorn A., 1999. Monitoring competition in young mixed plantations with broad-leaved tree species: a case study. In: Olsthoorn A., Bartelink H., Gardiner J., Pretzsch H.,
Hekhuis H., and Franc A. (Eds.), Management of mixed-species forest: silviculture abd economics. DLO Institute for Forestry and Nature research (IBN-DLO), Wageningen, The Netherlands.

Riek W. and Stähr F., 2004. Eigenschaften typischer Waldböden im Nordostdeutschen Tiefland unter besonderer Berücksichtigung des Landes Brandenburg. Landesforstanstalt Eberswalde, Eberswalde, Germany.

Schmid I., 2002. The influence of soil type and interspecific competition on the fine root system of Norway spruce and European beech. Basic Appl. Ecol. 3: 339-346.

Stout D. and Sala A., 2003. Xylem vulnerability to cavitation in Pseutotsuga menziesii and Pinus ponderosa from contrasting habitats. Tree Physiol. 23: 43-50.

Suckow F., Badeck F., Lasch P., and Schaber J., 2001. Nutzung von LevelII-Beobachtungen für Test und Anwendung des Sukzessionsmodells FORESEE. Beiträge für Forstwirtschaft und Landschaftsökologie 35: 84-87.

Tiktak A. and Bouten W., 1990. Soil hydrological system characterization of the two ACIFORN stands using monitoring data and the soil hydrological model "SWIF". Dutch priority programme on acidification, Wageningen, The Netherlands.

Tiktak A., and Bouten W., 1994. Soil-water dynamics and long-term water balances of a Douglas-fir stand in the Netherlands. J. Hydrol. 156: $265-283$.

Tiktak A., Konsten C., Maas R.V.D., and Bouten W., 1988. Soil chemistry and physics of two Douglas-fir stands affected by acid atmospheric deposition on the Veluwe, the Netherlands. Dutch priority programme on acidification, Wageningen, The Netherlands.

Van den Hurk B., Tank A., Lederink G., Ulden A.V., Oldenborgh G.V., Katsman C., Brink H.V.D., Keller F., Bessembinder J., Burgers G., Komen G., Hazeleger W., and Drijhout S., 2006. Climate change scenarios 2006 for the Netherlands. KNMI (Royal Dutch Meteorological Institute), de Bilt, The Netherlands.

Van der Werf G., Sass-Klaassen U., and Mohren G.M.J., 2007. The impact of the 2003 summer drought on the intra-annual growth pattern of beech (Fagus sylvatica L.) and oak (Quercus robur L.) on a dry site in the Netherlands. Dendrochronologia 25: 103-112.

Verkaik E., Moraal L., and Nabuurs G., 2009. Potential Impacts of climate change on Dutch forests - Mapping the risks. In, Alterra-report, Wageningen, p. 84. 